\title{
SENGKETA SERTIFIKAT HAK GUNA BANGUNAN DI PENGADILAN TATA USAHA NEGARA MAKASSAR DALAM PERSPEKTIF HUKUM ISLAM
}

\author{
AMRIANI, AHMAD M. SEWANG \\ Fakultas Syariah dan Hukum Universitas Islam Negeri Alauddin Makassar
}

\begin{abstract}
Abstrak
Pandangan Hukum Islam tentang sengketa adalah Konflik dan sengketa yang terjadi di kalangan umat manusia merupakan suatu realitas karena manusia dibekali akal dan wahyu serta mampu menemukan pola penyelesaian sengketa sehingga penegakan keadilan dapat terwujud. Sengketa yang di lakukan di Pengadilan tata usaha Negara Makassar adalah lingkungan peradilan dibawa mahkama agung yang melaksanakan kekuasaan kehakiman bagi rakyat pencari keadilan terhadap sengketa Tata Usaha Negara. Jadi dalam penyelesaian sengketa Tata Usaha negara dapat di lakukan dengan tiga cara yaitu prosedur, subtansi dan kepentingan. adapun pertimbangan hukum hakim ada dua yaitu pertimbangan menurut ketentuan hukum Agrariya dan hukum Peradilan Tata Usaha Negara. Pola penyelesaian sengketa dapat dirumuskan manusia dengan merujuk pada sejumlah ayat al-Quran, hadis Nabi, praktek adat dan berbagai kearifan lokal.
\end{abstract}

Kata Kunci : Hak Guna Bangunan, Hukum Islam, Sengketa, Sertifikat.

\begin{abstract}
The view of Islamic law on disputes is that conflicts and disputes that occur among humanity are a reality because humans are equipped with reason and revelation and are able to find patterns of dispute resolution so that justice can be realized. The dispute carried out in the Makassar State Administrative Court is a judicial environment brought by the Supreme Court which exercises judicial power for the people seeking justice for the State Administration dispute. So in the settlement of a state administration dispute can be done in three ways, namely procedures, substance and interests. As for the legal considerations of judges, there are two, namely considerations according to the provisions of Agrarian law and the law of the State Administrative Court. Patterns of dispute resolution can be formulated by humans by referring to a number of verses of the paper, hadith of the prophet, customary practices and various local wisdoms.
\end{abstract}

Keywords: Building Rights, Certificates, Disputes, Islamic Law. 


\section{A. PENDAHULUAN}

Sengketa Tata Usaha Negara adalah sengketa yang timbul dalam bidang Tata Usaha Negara antara orang atau badan Hukum perdata atau pejabat Tata Usaha Negara, baik di pusat maupun di daerah, sebagai akibat dikeluarkannya keputusan Tata Usaha Negara, termasuk sengketa kepegawaian berdasarkan peraturan perundang-undangan yang berlaku. ${ }^{1}$

Hukum Administrasi Negara adalah seperangkat aturan yang memungkinkan administrasi negara menjalankan fungsinya yang sekaligus juga melindungi warga terhadap sikap tidak administrasi Negara dan melindungi administrasi Negara itu sediri. Dalam hukum administrasi Negara terkandung dua aspek yang pertama aturan-aturan hukum yang mengatur dengan cara bagaimana alat-alat perlengkapan Negara itu melakukan tugasnya, yang kedua yaitu aturan-aturan hukum yang mengatur hubungan hukum antara alat perlengkapan administrasi Negara atau pemerintah dengan para warga Negaranya. ${ }^{2}$

Hukum administrasi sebagai hukum publik memiliki aspek materil maupun formil, aspek materil hukum administrasi Negara terdiri dari norma atau kaidahkaidah yang mengatur tentang jabatan, tugas dan wewenang jabatan dan resiko tindakan jabatan dalam arti mengatur bagaimana harusnya pejabat menjalankan kekuasaan pemerintahan, ketika tugas dan jabatan wewenang yang dimaksud dijalankan bertentangan dengan Norma atau kaidah hukum yang ditetapkan maka akan timbul konflik hukum atau sering di istilahkan dengan sengketa administrasi. ${ }^{3}$

Hal yang dapat memicu terjadinya sengketa dapat terlihat dari sistem publikasi pendaftaran tanah yang digunakan di Indonesia, yaitu publikasi Negatif yang mengandung unsur Positif, ${ }^{4}$ sebagaimana dinyatakan dalam pasal 19 ayat (2) huruf c Undang-Undang pokok Agraria bahwa pendaftaran menghasilkan surat-surat tanda bukti hak yang berlaku sebagai alat pembuktian yang kuat dan bukan mutlak, (surat tersebut tidak bisa diganggu gugat oleh pihak lain). Sehingga tanah yang sudah didaftarkan dan dikeluarkan tanda bukti haknya tidak dijamin kebenarannya sebagai milik dari orang yang tedaftar namanya dalam tanda bukti atas tanah tersebut.

Penjelasan peraturan pemerintahan Nomor 10 Tahun 1961 tentang pendaftaran tanah dalam penjelasan umum c/7 menentukan bahwa:

"Pembukaan suatu hak dalam daftar buku tanah atas nama seseorang tidak mengakibatkan bahwa orang yang sebenarnya berhak atas tanah itu akan kehilangan haknya; orang tersebut masih dapat menggugat haknya dari orang yang terdaftar dalam buku tanah sebagai orang yang berhak. Sesuai dengan pasal 1 PP Pendaftaran Tanah, ditegaskan bahwa pendaftaran tanah merupakan kegiatan pemerintah. Hal ini berarti bahwa proses pendaftaran hak atas tanah merupakan kewenangan dari pemerintah dan dilaksanakan oleh BPN melalui kantor pertanahan Kabupaten atau Kota yang sesuai dengan pasal 5 PP Pendaftaran Tanah. Berdasarkan Perpres No.10 2006 tentang Badan Pertanahan

${ }^{1}$ Zairin Harahap, Hukum Acara Peradilan Tata Usaha Negara, (Jakarta: PT. Raja Grafindo Persada, 2008), h.63.

${ }^{2}$ Ridwan, Hukum Administrasi Negara, (Cet. X; Jakarta: PT. Raja Grafindi Persada, 2014), h.37

${ }^{3}$ Andi Safriani, Hukum Administrasi Negara, h.217

${ }^{4}$ Farin Widinenda, Sengketa Penguasaan Tanah Hak Guna Bangunan dan Upaya Penyelesaiannya, Vol. 14. Farin-Widinenda.ac.id. 
Nasional selanjutnya dapat disebut Perpres BPN, pasal 2 Perpres BPN telah menegaskan tugas BPN membantu Presiden dalam mengelola dan mengembangkan administrasi pertanahan baik berdasarkan UUPA maupu peraturan UU. Berdasarkan UU Administrasi Pemerintahan pasal 1 angka 3 menegaskan bahwa pejabat pemerintahan adalah unsur yang melaksanakan fungsi pemerintahan baik dilingkungan pemerintah maupun penyelenggara Negara lainnya."5

Pasal 115 Undanag-Undang Nomor 5 Tahun 1986 tentang peradilan Tata Usaha Negara sebagaimana yang telah beberapa kali mengalami perubahan dan berakhir dengan Undang-Undang Nomor 51 Tahun 2009 tentang perubahan kedua atas Undang-Undang Nomor 5 Tahun 1986 tentang Peradilan Tata Usaha Negara menyatakan "Hanya putusan pengadilan yang telah memperoleh kekuatan hukum tetap yang dapat dilaksanakan". Sementara ketentuan dalam pasal 116 ayat (2) Undang-Undang Nomor 5 Tahun 1986 tentang peradilan Tata Usaha Negara yang beberapakali mengalami perubahan kedua atas Undang-Undang No.5 Tahun 1986 tentang Peradilan Tata Usaha Negara menyatakan"Apabila setelah 60 hari kerja putusan pengadilan yang telah memperoleh kekuatan hukum tetap sebagaimana dimaksud pada ayat 1 diterima tergugat tidak melaksanakan kewajibannya sebagaimana dimaksud dalam pasal 97 ayat (9) huruf a, maka keputusan Tata Usaha Negara yang disengketakan itu tidak mempunyai kekuatan hukum lagi. ${ }^{6}$

Berdasarkan Undang-Undang No. 30 Tahun 2014 tentang administrasi pemerintahan selanjutnya disebut Undang-Undang Administrasi Pemerintahan, pasal 1 angka 1 menegaskan bahwa badan atau pejabat pemerintahan adalah unsuryang melaksanakan unsur pemerintahan baik di lingkungan pemerintah maupun penyelenggara negara lainnya. Sedangkan Undang-Undang No.5 Tahun 1986 tentang Peradilan Tata Usaha Negara sebagaimana di ubah dengan Undang-Undang Nomor 51 Tahun 2009 tentang perubahan kedua Undang-Undang Nomor 5 Tahun 1986 selanjutnya disebut Undang-Undang PTUN kedua, berdasarkan pasal 1 angka 8 Undang-Undang PTUN kedua menegaskan bahwa yang dimaksud dengan badan atau pejabat TUN adalah badan yang melaksanakan urusan pemerintahan berdasarkan peraturan-peraturan perundangan yang berlaku. ${ }^{7}$

Pemerintah mempunyai kewajiban untuk mengatur pemanfaatan tanah serta menjamin kepastian hukum dan perlindungan hukum bagi pemegang hak atas sebidang tanah yang dimilikinya sehingga tanah dapat berfungsi secara optimal untuk meningkatkan kemakmuran bagi rakyat sesuai dengan amanat pasal 33 (3) Undang-Undang Dasar 1945. Pendaftaran tanah yang dilaksanakan berdasarkan UUPA bertujuan untuk menjamin kepastian dan perlindungan hukum kepada pemegang hak atas tanah agar dengan mudah dapat membuktikan dirinya sebagai

5 Boedi Harsono, Hukum Agraria Indonesia, Sejarah Pembentukan Undang-Undang Pokok Agraria Isi dan Pelaksanaannya, (Jakarta: Djambatan, 2013), h. 83.

${ }^{6}$ Rani Arfita, Kedudukan Badan Pertanahan Nasional dalam Menghadapi Problematika Putusan PTUN Tentang Pembatalan Sertifikat Hak Atas Tanah, Vol.23.No.1 Juni 2016. Jornal.umy.ac.id/index.

${ }^{7}$ Fani Martiawan Kumala Putra, Pembatalan Sertifikat Hak Atas Tanah karena Cacat Administrasif serta Implikasinya terhadap Tanah yang akan di Jaminkan, Vol. XX No. 2 (MEI 2015), h.106. ajaurnal-perspektif.org/index.php/perspektif/article/viewfile/.../pdf_1 
pemegang hak atas tanah yang besangkutan dan untuk terlaksananya tertip administrasi pertanahan. ${ }^{8}$

Dilihat dari konsep dasar hukum administrasi Negara sebagai bagian dari hukum publik dan sebagai instrumen yuridis, diperlukan seperangkat lembaga atau badan yang berfungsi untuk menegakkan hukum administrasi dari aspek materil, lembaga atau badan yang dimaksud adalah peradilan administrasi yang dalam kepustakaan belanda dikenal denganAdministratief Rechspraak.

Hukum yang diterapkan adalah peradilan administrasi itu dilihat dari pangkal sengketa sebagai salah satu tolak ukur secara horisontal dan atribusi wewenang peradilan administrasi, yang menjadi pangkal sengketa ialah ketetapan tertulis, ketetapan tertulis itu harus mengandung perbuatan administrasi Negara yang bertidak didalam fungsinya akan tetapi perbuatan itu melawan hukum. ${ }^{9}$

Dalam hukum Islam, kepemilikan tanah oleh sesorang dalam konteks individual dalam relasi sosial secara yuridis, diakui. Pemilik tanah mempunyai kewenangan untuk menggunakan (Tasarruf), sesuai dengan keinginannya, kewenangan manusia atas kepemilikan harta (haq al-milkiyyah property right), dalam kaidah hukum islam dilindungi dalam bingkai hifzu al- mal sebagai salah satu prinsip al;kulliyah alkhams. Tanah, di samping sebagai instrument ekonomis, juga mempunyai kandungan sosial humanistik. ${ }^{10}$

Oleh karena itu, islam melarang melakukan praktek monopoli aset atau harta. Dengan demikian, pemilikan harta oleh seseorang haruslah disertai dengan pertanggung jawaban secara moral. Kepemilikan seseorang atas tanah sebagaimana kepemilikan atas harta benda yang lainnya, dalam penggunaannya haruslah mempertimbangkan aspek-aspek sosial. Kebebasan seseorang atas hak miliknya dibatasi oleh hak-hak orang lain baik secara individual maupun kelompok.

Salah satu contoh kasus mengenai sengketa sertifikat hak guna bangunan yang di angkat di hadapan sidang Pengadilan Tata Usaha Negara yaitu sengketa dengan register nomor 36/G.TUN/2012/P.TUN.Mks yang terdaftar di Kepaniteraan Pengadilan Tata Usaha Negara Makassar pada tanggal 23 Mei 2012. Adapun yang menjadi objek dalam gugatan ini adalah surat keputusan yang diterbitkan oleh Kepala Kantor Pertanahan Kota Makassar atau tergugat berupa Sertifikat Hak Guna Bangunan Nomor 20029/Kel. Bara-Baraya Selatan atau 2005, tanggal 8 April 2005, Surat ukur Nomor 00155/2004 tanggal 22 Desember 2004 seluas $924 \mathrm{~m}^{2}$, atas nama Perserikatan Muhammadiyah/objektum litis. Bahwa dasar penerbitan sertifikat hak guna bangunan surat ukur nomor 20029/2004, seluas $924 \mathrm{~m}^{2}$ atas nama Perserikatan Muhammadiyah adalah surat keputusan Kepala Kantor Pertanahan Makassar tanggal tanggal 24 maret 2005.

Pada tanggal 12 Mater 2012 para penggugat Masyarakat Kelurahan BaraBaraya Selatan, dan Tokoh Masyarakat diundang oleh pihak Perserikatan Muhammadiyah, dalam pertemuan itu oleh pihak Perserikatan Muhammadiyah mengatakan bahwa tanah yang dibanguni Masjid Babul Jihad dan Tk.Aisyah adalah tanahnya dan memperlihatkan sertifikat Hak Guna Bangunan Nomor: 20029/Kel.Bara-Baraya Selatan/2015, seluas $924 \mathrm{~m}^{2}$ atas nama Perserikatan

\footnotetext{
${ }^{8}$ Samun Ismaya, Hukum Administrasi Petanahan (Cet. I; Yogyakarta: Graha Ilmu, 2013), h.82.

${ }^{9}$ Andi Safriani, Hukum Administrasi Negara, h.219

${ }^{10}$ Ridwan, Pemilikan Rakyat dan Negara atas Tanah, h.12-13
} 
Muhammadiyah. Kepada para pengguggat baru mengetahui bahwa di atas terbitlah sertifikat Hak Guna Bangunan, dan para penggugat mengajukan gugatan di Pengadilan Tata Usaha Negara Makassar pada tanggal 23 Mei 2012.

Bahwa berdasarkan alasan hukum tersebut diatas para penggugat kel.BaraBaraya Selatan memohon kepada Majelis Hakim Tata Usaha Negara Makassar agar mengabulkan gugatan para penggugat untuk seluruhnya dan membatalkan atau menyatakan tidak sah Surat Keputusan Tata Usaha Negara berupa Sertifikat Hak Guna Bangunan.

\section{B. METODE PENELITIAN}

Jenis penelitian ini tergolong kualitatif lapangan dengan pendekatan penelitian yang dipergunakan adalah pendekatan teologi Normatif dan pendekatan sosiologis. Adapun sumber data penelitian ini adalah hakim dan panitera Pengadilan Tata Usah Negara Makassar metode pengumpulan data yang digunakan adalah observasi, wawancara, dokumentasi, dan studi kepustakaan, teknik pengolahan data dan analisis data dilakukan dengan melalui empat tahapan, yaitu: klarifikasi data, reduksi data, koding data, dan editing data.

\section{PEMBAHASAN}

1. Kasus posisi sengketa sertifikat hak guna bangunan di Pengadilan Tata Usaha Negara Makassar: 36/G.TUN/2012/P.TUN/Mks

Pihak yang berperkara dalam perkara Tata Usaha Negara Makassar Nomor: 36/G.TUN/2012/P.TUN.Mks.

a. Identitas Penggugat

Para penggugat 1 sampai 77 Masyarakat Kelurahan Bara-Baraya Selatan, Kecamatan Makassar, Kota Makassar, dalam hal ini diwakili oleh kuasa hukumnya yang bernama SUHARDI SH dan MURSYINUDDIN ADDAS SH masing-masing Advokat atau konsultan Hukum, berkantor pada Kantor Advokat Suhardi, SH, Dkk di Jalan Pallantikang nomor 32 Sungguminasa, Kelurahan Katangka, Kecamatan Somba Opu, berdasarkan surat kuasa khusus tertanggal 21 Mei 2012.

b. Identitas Tergugat

Kepala kantor pertanahan kota makassar, berkedudukan di Jalan A.P.Pettarani Makassar. Yang diwakili oleh kuasa Hukumnya Misniati Sinaga S.H Jabatan Kepala Sub Seksi Perkara pada Kantor Pertanahan Kota Makassar, Hamzah S.H Kepala Sub Seksi Sengketa dan Konflik Pertanahan pada Kota Makassar, berdasarkan Surat Kuasa khusus tertanggal 12 Juni 2012 Nomor 431/SK.600.1473.71/VI/2012. Dan PERSERIKATAN MUHAMMADIYAH berkedudukan di Jalan Lompo Battang Bomor 201 Makassar, di wakili oleh kuasa Hukumnya GAZALI ABD.RACHMAN, S.H., AGUSSALIM, S.H., MUHAMMAD BASRA BASRI, S.H., HERMAN, S.H., semuanya Warga Negara Indonesia, pekerjaan pengurus Majelis Hukum dan Hak Asasi Manusia (HAM) Pimpinan Muhammdiyah Kota Makassar Beralamat di Jalan Gunung Lompobattang nomor 201 Makassar, berdasarkan Surat Kuasa 355/1.0/1/2015.

Duduk Perkara dalam Perkara Tata Usaha Negara Makassar Nomor 36/G.TUN/2012/P.TUN.Mks.

a. Dasar Gugatan Penggugat

Dasar gugatan penggugat dalam gugatan ini adalah: 
1) Penggugat Masyarakat Kelurahan Bara-baraya Selatan menguasai tanah Eigendom Vetponding Nomor 1166 seluas $60.000 \mathrm{M}^{2}$ dengan batas-batas yang telah diuraikan dalam surat ukur Nomor: 00155/2004 tanggal 22 Desember 2004 seluas $924 \mathrm{M}^{2}$ atas nama Perserikatan Muhammadiyah adalah surat keputusan kantor pertanahan kota Makassar tanggal 24 Maret 2005. Dan tidak penyerahan atau pengalihan atas tanah seluas $924 \mathrm{M}^{2}$ Objek Sertifikat Hak Guna Bangunan atas nama Perserikatan Muhammadiyah bertentangan dengan pasal 25 huruf (a) 1 dan 2 Peraturan Pemerintah RI Nomor 24 Tahun 1997 tentang pendaftaran Tanah yang melanggar Pasal 53 Ayat 2 Huruf (a) (b) dan (c) Undang-Undang RI Nomor 9 Tahun 2004 tentang perubahan atasUndang-Undang Undang-Undang RI Nomor 5 Tahun 1986 tentang Peradilan Tata Usaha Negara.

2) Bahwa pihak Tergugat Kepala Kantor Pertanahan Kota Makassar tidak pernah melakukan pengukuran atas tanah seluas $924 \mathrm{M}^{2}$ yang diatasnya berdiri bangunan Mesjid Babul Jihad dan SD Filial atau TK Aisyah. Dan Tergugat Kepala Kantor Peranahan Kota Makassar tidak pernah mengumumkan baik secara lisan maupun tertulis yang ditempel di Mesjid Babul Jihad sebab Para penggugat Masyarakat Bara-baraya Selatan Selalu ada yang berada didalam Mesjid dan tidak pernah melihat atau mendengar pengumuman yang ditempel oleh pihak tergugat.

3) Berdasarkan alasan Hukum tersebut maka para Penggugat memohon kepada Majelis Hakim Tata Usaha Negara Makassar memeriksa dan mengadili perkara ini dan mengabulkan gugatan para penggugat bahwa tindakan tergugat yang mengeluarkan surat atau menerbitkan Surat Keputusan berupa Sertifikat Hak Guna Bangunan Nomor: 20029/Kelurahan Bara-Baraya Selatan dengan Tanah seluas $924 \mathrm{M}^{2}$ atas nama Perserikatan Muhammadiyah melanggar pasal 26 Ayat 1 dan 2 Peraturan Pemerintah RI Nomor 24 Tahun 1997 tentang Pendaftara Tanah. Membatalkan atau menyatakan tidak sah dan mewajibkan tergugat mencabut Surat Keputusan Tata Usaha Negara berupa Sertifikat Hak Guna Bangunan Nomor: 20029/Kelurahan Bara-Baraya Selatan, mewajibkan tergugat.

b. Jawaban Tergugat

Bahwa tergugat menyatakan menolak seluruh positum gugatan dan petitum penggugat dalam Surat Gugatannya.

1) Bahwa Gugatan Penggugat telah Kadaluarsa (Verjaring), bahwa gugatan para penggugat telah melampaui waktu 90 hari sebagaimana disyaratkan dalam pasal 55 Undang-Undang Nomor 5 Tahun 1989, bahwa Penggugat salah dalam mengajukan gugatan atau tidak tepat. Berdasarkan alasan Hukum tersebut diatas bahwa tergugat memohon kepada Majelis Hakim untuk memutus perkara ini dengan menyatakan gugatan penggugat dinyatakan ditolak atau setidak-tidaknya gugatan tidak dapat diterima.

2) Pembuktian dalam perkara Nomor 36/G.TUN/2012/P.TUN.Mks di Pengadilan Tata Usaha Negara Makassar (PTUN)

a) Bukti yang diajukan Penggugat

Surat berupa foto kopi yang diberi materai secukupnya dan diberi tanda P-1 foto kopi tanda aslinya penetapan tugas pokok masing-masing pengurus mesjid babhul jihad Bara-Baraya Selatan, sampai dengan p-54. Selain mengajukan alat bukti surat pihak para penggugat mengajukan 11 orang saksi di Persidangan.

b) Bukti yang diajukan Tergugat 
Untuk menguatkan bantahannya tergugat mengajukan bukti surat berupa foto kopi yang diberi tanda T-1 sampai dengan T-9. T.II.Int-I foto kopi sesuai buktinya buku tanah hak guna bangunan nomor 200029/Kelurahan BaraBaraya Selatan, surat ukur Nomor: 00155/2005 luas $924 \mathrm{M}^{2}$ atas nama Perserikatan Muhammadiyah, sampai bukti T.II.Int-37.

c) Pemeriksaan setempat

Menimbang bahwa telah diadakan pemeriksaan setempat pada hari selasa tanggal 14 Agustus 2012, oleh Majelis Hakim bersama oleh para pihak dilokasi yang dimaksud dalam objek sengketa di Jalan Abubakar Lambogo, Kelurahan Bara-Baraya Selatan, Kecamatan Makassar, Kota Makassar.

3) Pertimbangan Hukum Hakim dalam Perkara Nomor: 36/G.TUN/2012/ P.Tun/MKS di Pengadilan Tata Usaha Makassar (PTUN)

ATAS Eksepsi, Replik Tergugat atau Penggugat, Majelis Hakim mempertimbangkan sebagai berikut:

a. Dalam Eksepsi, Majelis Hakim akan mempertimbangkan terlebih dahulu Eksepsi Tergugat dan tergugat II Intervensi ke-2 yaitu Eksepsi tentang para Penggugat salah dalam mengajukan gugatan (Kompotensi Absolut), karena Eksepsi ini akan menentukan apakah Peradilan Tata Usaha Negara Makassar berwenang memeriksa memutus dan menyelesaikan sengketa ini.

b. Menimbang berdasarkan fakta-fakta yang terurai dalam gugatan para penggugat tersebut, menurut hamar majelis hakim telah sesuai dengan maksud pasal 1 angka 9, 12 dan 56 Undang-Undang Nomor 5 Tahun 1986 Jo.

c. Menimbang berdasarkan pada pertimbangan hukum diatas, Majelis Hakim berpendapat bahwa sengketa In Litis adalah kewenangan Pengadilan Tata Usaha Negara Makassar untuk memeriksa, memutus dan menyelesaikannya, karena Eksepsi tergugat dan Tergugat II Intervensi dalam hal ini tidak beralasan Hukum dan patut untuk ditolak.

d. Menimbang bahwa selanjutnya majelis Hakim akan mempertimbangkan Eksepsi Tergugat dan Tergugat dan tergugat II Intervensi ke-1 yaitu tentang Gugatan Para Penggugat telah kadaluwarsa.

e. Menimbang bahwa sesuai dengan Jurisprudensi Mahkamah Agung RI sebagai berikut:

1) Reg.Nomor: 5 K/TUN/1992, tanggal 21 Januari 1993.

2) Reg.Nomor: $41 \mathrm{~K} / \mathrm{TUN} / 2004$, tanggal 19 November 1994.

3) Reg.Nomor: $270 \mathrm{~K} / \mathrm{TUN} / 2001$, tanggal 4 Maret 2002.

Terkandung kaidah Hukum, bahwa tenggang waktu gugatan pada pihak ke-3 yang tidak ditunjuk langsung pada sebuah keputusan Tata Usaha Negara yang merugikan kepentingannya adalah 90 hari terhitung secara kasuistis sejak mengetahui akan adanya keputusan yang merugikan kepentingannya tersebut.

f. Menimbang bahwa majelis hakim mencermati jawab jinawab para penggugat, tergugat dan tergugat II Intervensi majelis hakim berpendapat bahwa para penggugat adalah pihak yang tidak ditunjuk langsung dalam oleh surat keputusan tersebut. Menimbang bahwa atas jawab jinawab para penggugat dan tergugat serta tergugat II Intevensi tersebut, majelis Hakim akan menguji apakah para penggugat memiliki kepentingan yang dirugikan atas terbitnya sertifikat tersebut. 
g. Menimbang setelah Majelis Hakim mencermati bukti P-7 yaitu surat keputusan ketua pengurus Mesjid babul Jihad, kemudian menimbang bahwa Majelis Hakim akan mempertimbangkan Eksepsi Tergugat dan Tergugat II Intervensi ke-5 yaitu Eksepsi gugatan para Penggugat kabur.

h. Menimbang bahwa lebih dari itu dalam sengketa di Peradilan Tata Usaha Negara Hakim pada peradilan Tata Usaha Negara bersifat Dominus Litis artinya Hakim tidak terkait sepenuhnya dengan dalil-dalil Gugatan Penggugat akan tetapi hakim dapat menilai apa yang menjadi permasalahan pokoknya. Berdasarkan Eksepsi Tergugat dan Tergugat II Intervensi yang ditolak maka Majelis Hakim akan mempertimbangkan mengenai pokok Perkaranya.

Dalam pokok perkara, Menimbang bahwa dalam pokok perkara pertama Majelis Hakim akan mempertimbangkan bahwa oleh karena Eksepsi Tergugat dan Tergugat II Intervensi kaitannya dengan kedudukan penggugat selain 1,2,3,4,5 dan 6 secara Hukum Harus dinyatakan tidak dapat diterima.

Menimbang bahwa berdasarkan pada fakta-fakta Hukum tersebut diatas Majelis Hakim berpendapat bahwa tanah sebagaimana dimaksud dalam objek sengketa adalah tanah negara yang dikuasai oleh pemerintah Kotamadya Ujung Pandang, sekarang Kota Makassar.

Menimbang bahwa demikian keseluruhan Alat bukti surat dan keterangan saksi yang diajukan oleh pihak-pihak telah dipertimbangkan, akan tetapi hanya bukti yang relavan saja yang dijadikan dasar pertimbangan oleh majelis Hakim dalam mengambil putusan.

2. Analisis Kasus terhadap Sengketa sertifikat hak gunan bangunan di Pengadilan Tata Usaha Negara Makassar dalam Perspektif Hukum Islam

Penyelesaian sengketa sertifikat hak guna bangunan di Pengadilan Tata Usaha Negara Makassar Terkait dengan masalah penyelesaian harus dilihat dari semua prosedur perkara, maka ada tiga yang harus dilihat yaitu dari segi prosedur, subtansi, dan kepentingan. dari segi kepentingan harus dilihat apakah memiliki kepentingan atau tidak bagi yang menggugat dengan Hak Guna Bangunan yang dicabut. Prosedur apakah pencabutan hak guna bangunannya sah atau tidak. Dari segi subtansi mengenai subtansi materil semua kita uji dari aspek undang-undang Peraturan Pemerintah (PP) RI Nomor: 24 Tahun 1997 tentang pendaftaran tanah, dan ketentuan pasal 107 Undang-Undang Nomor 5 Tahun 1986 tentang peradilan Tata Usaha Negara.

Dasar pertimbangan hukum Hakim dalam perkara Nomor: 36/G.TUN/2012/ P.TUN.MKS berdasarkan peraturan yang berlaku

a. Pertimbangan menurut ketetuan hukum Agraria.

Dasar permohonan penertbitan bertentangan dengan pasal 23 Huruf (a) 1 dan 2 Peraturan Pemerintah (PP) RI Nomor: 24 Tahun 1997 tentang pendaftaran tanah, karena pihak tergugat kepala kantor pertahanan kota makassar tidak pernah mengadakan pengukuran atas tanah seluas $924 \mathrm{~m} 2$ yang diatasnya terdiri bangunan Mesjid Babul Jihad dan SD Filial/TK Aisyah yang terletak dijalan abubakar lambogo 3 kelurahan Bara-Baraya selatan kecamatan makassar. Begitu juga dari pihak perserikatan Muhammadiyah tidak pernah menyampaikan kepada penggugat bahwa tanah seluas $924 \mathrm{~m}^{2}$ yang diatasnya terdiri bangunan Mesjid Babul Jihad dan SD Filial/TK Aisyah yang terletak dijalan abubakar lambogo 3 kelurahan BaraBaraya Selatan Kecamatan Makassar atas nama Perserikatan Muhammadiyah 
melanggar pasal 26 ayat 1 dan 2 Peraturan Pemerintah (PP) RI Nomor 24 Tahun 1997 Tentang Pendaftaran Tanah. ${ }^{11}$

Dalam ketentuan pasal 23 huruf (a) 1 dan 2 Jo Pasal 60 ayat (2) huruf I Peraturan Pemerintah (PP) RI Nomor: 24 Tahun 1997 tentang pendaftaran tanah: Pasal 23: tentang keperluan pendaftaran, yang pertama penetapan pemberian hak dari pejabat yang berwenang memberikan hak yang bersangkutan menurut ketentuan yang berlaku apabila pemberian hak tersebut berasal dari tanah Negara atau tanah hak pengelolaan. Yang kedua Asli akta PPAT yang memuat pemberian hak tersebut oleh pemegang hak milik kepada penerima hak yang bersangkutan apabila mengenai hak guna bangunan dan hak pakai atas tanah hak milik. Pasal 60 ayat 2 huruf i dimana alat bukti tertulis yang digunakan untuk pendaftaran hak-hak lama sebagaimana dimaksud dalam pasal 24 ayat 1 Peraturan Pemerintahan Nomor 24 Tahun 1997 dinyatakan lengkap apabila dapat ditunjukkan kepada panitera Ajudikasi dokumendokumen. $^{12}$

b. Pertimbangan Hukum Menurut ketentuan Hukum Tata Usaha Negara.

Dalam perkara ini Majelis Hakim mempedomani ketentuan pasal 107 UndangUndang Nomor 5 Tahun 1986 tentang peradilan Tata Usaha Negara. Dalam hal ini hakim menentukan apa yan harus dibuktikan dan untuk sahnya pembuktian diperlukan sekurang-kurangnya dua alat bukti berdasarkan keyakinan Hakim. Pasal ini mengatur ketentuan dalam rangka usaha menemukan kebenaran material. ${ }^{13}$

Pendapat penulis terhadap perkara Nomor: 36/G.TUN/2012/P.TUN.MKS. Dalam perkara Peradilan Tata Usaha Negara pihak yang berperkara selanjutnya disebut PTUN, terdiri dari pihak penggugat dan pihak tergugat. Para pihak yang bersengketa tersebut masing-masing dapat didampingi atau diwakili oleh seseorang atau beberapa seorang kuasa. Pemberian kuasa ini dapat dilakukan dengan surat kuasa khusus atau dapat dilakukan secara lisan dipersidangan.

Berdasarkan ketentuan pasal 53 UU Nomor 5 Tahu 1986 dapat disimpulkan bahwapenggugat dalam sengketa Tata Usaha Negara adalah individu atau badan hukum perdata yang merasa dirugikan kepentingannya karena keputusan yang diterbitkan oleh Pejabat Tata Usaha Negara.

\section{Pandangan Hukum Islam}

Hukum Islam sebagai sumber hukum dapat dikatakan bahwa hukum Islam dalam bidang keperdataan dapat berlaku atas kesadaran atau pilihan sendiri tanpa pemaksaan melalui hukum formal. Sedangkan yang menyangkut hukum publik seperti hukum pidana, hukum Tata Negara, Hukum Administrasi Negara yang berlaku adalah hukum Nasional yang sumbernya dapat bermacam-macam dan hukum Islam merupakan salah satu di antaranya. Bahwa hukum Islam menjadi sumber hukum Nasional bersama hukum barat dan hukum adat, bukan berarti ia harus menjadi hukum formal. ${ }^{14}$

Dalam bahasa arab peradilan biasa disebut al-qadha' yang secara etimologis mengandung beberapa arti, (1) al-fragh, (2) al-ada', (3) al-hukm, (4) imdha, dan (5) alhatm wa al-ilzm. Sedangkan menurut istilah peradilan terdapat pengertian antara lain,

\footnotetext{
${ }^{11}$ Joko Setiono. SH.MK., Majelis Hakim.

12 Joko Setiono. SH.MK., Majelis Hakim.

${ }^{13}$ Joko Setiono. SH.MK., Majelis Hakim.

${ }^{14}$ Moh. Mahpud, Perdebatan Hukum Tata Negara, (Cet. II; Jakarta: PT. Raja Grafindo Persada,
} 2010), h. 244. 
peradilan (al-qadha') adalah suatu keputusan produk pemerintahan, atau menyampaikan hukum syara' dengan jalan penetapan. Dengan demikian apabila dikatakan qadha' alqadhi', maka berarti al-zamaal- haqqa ahlahu. Pengertian ini adalah bermaksud melaksanakan dan menunaikan perintah agama, dan bukan menciptakan hukum. ${ }^{15}$

Tidak bisa dipungkiri dalam kehidupan manusia akan selalu terjadi perbedaan pendapat yang bahkan menyebabkan perselisihan diantara masing- masing orang yang bersengketa. Begitu pula terkait masalah perselisihan yang diakibatkan oleh perebutan hak milik tanah yang sampai membuat orang terkadang lalai dan melakukan hal yang buruk seperti ingkar janji, berdusta, bahkan sampai berkhianat seperti dalam firman Allah swt. Dalam Al-Qur'an Surah Al-Huujurat Ayat 9 dan terjemahannya:

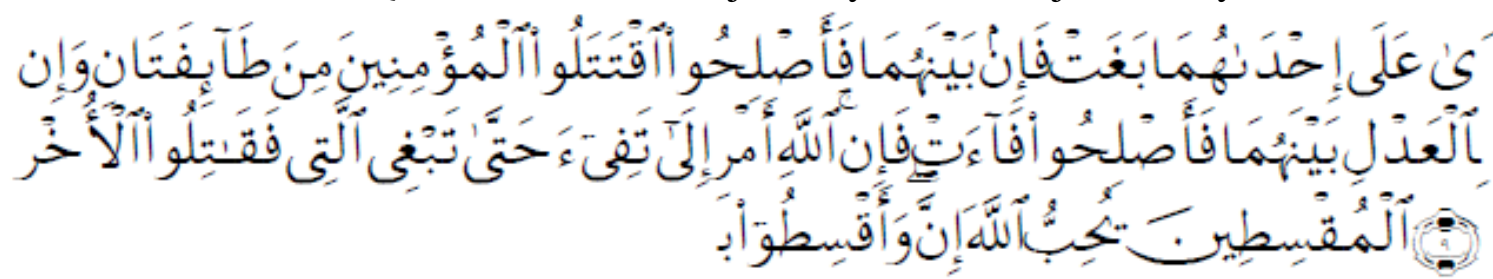

Terjemahannya:

"Dan kalau ada dua golongan dari mereka yang beriman itu berperang hendaklah kamu damaikan antara keduanya! Tapi kalau yang satu melanggar Perjanjian terhadap yang lain, hendaklah yang melanggar perjanjian itu kamu perangi sampai surut kembali pada perintah Allah. Kalau dia telah surut, damaikanlah antara keduanya menurut keadilan, dan hendaklah kamu berlaku adil; sesungguhnya Allah mencintai orang-orang yang Berlaku adil."

Konflik dan sengketa yang terjadi di kalangan umat manusia adalah suatu realitas, manusia sebagai khalifah-Nya di bumi dituntut untuk menyelesaikan sengketa, karena manusia dibekali akal dan wahyu dalam menata kehidupannya. Manusia harus mencari dan menemukan pola penyelesaian sengketa sehingga penegakan keadilan dapat terwujud. Pola penyelesaian sengketa dapat dirumuskan manusia dengan merujuk pada sejumlah ayat al-Quran, hadis Nabi, praktek adat dan berbagai kearifan lokal. Kolaborasi dari sumber ini akan memudahkan manusia mewujudkan kedamaian dan keadilan.

Eksistensi peradilan Tata Usaha Negara dipertegas lagi dengan dikeluarkannya Undang-Undang No.5 Tahun 1986 tentang Peradilan Tata Usaha Negara. Pengadilan Tata Usaha Negara bertugas dan berwenang memeriksa, memutus serta menyelesaikan sengketa Tata Usaha Negara. Dalam hal suatu pejabat atau badan Tata Usaha Negara, diberi wewenang oleh atau berdasarkan peraturan perundang-Undangan untuk menyelesaikan secara Administratif sengketa Tata Usaha Negara tertentu, maka sengketa Tata Usaha Negara tersebut harus diselesaikan melalui upaya administratif yang tersedia. Pengadilan baru mempunyai wewenang memeriksa, memggadili serta memutus sengketa Tata Usaha Negara sebagaimana dimaksud dalam ayat (1) jika seluruh upaya administratif yang bersangkutan telah digunakan. ${ }^{16}$

Pengadilan tidak berwenang memeriksa, memutus serta menyelesaikan sengketa Tata Usaha Negara tertentu dalam hal keputusan yang disengketakan ini dikeluarkan dalam keadaan:

\footnotetext{
${ }^{15}$ Andi Intan Cahyani, Peradilan dan Hukum Keperdataan Islam (Cet. I; Alauddin University Press, 2014), h. 4.

${ }^{16}$ Andi Intan Cahyani, Peradilan dan Hukum Keperdataan Islam, h. 90.
} 
1. Waktu perang, keadaan bencana Alam, keadaan bahaya, keadaan luar biasa yang membahayakan berdasarkan peraturan perundang-undangan yang berlaku.

2. Mendesak untuk kepentingan umum berdasarkan peraturan perundang- undangan yang berlaku yang dimaksud dalam kepentingan umum disini adalah kepentingan bangsa dan negara dan / atau kepentinga masyarakat bersama dan / atau pembangunan, sesuai dengan peraturan perundang- undangan yang berlaku. ${ }^{17}$

Islam memandang Negara sebagai institusi yang mengelolah masyarakat suatu Negara. Atas dasar inilah, islam memberikan hak sekaligus kewajiban kepada institusi tersebut untuk mengatur relasi antar individu, individu dengan masyarakat, serta hubungan individu dan masyarakat dan Negara. Dalam hal pengaturan fungsi-fungsi sosial tanah, pemerintah (Imam) mempunyai otoritas untuk membuat regulasi terkait dengan tanah untuk mengatur dan menata penggunaan tanah dan menciptakan kemaslahatan umum. Nabi Muhammad, dalam kapasitasnya sebagai seorang imam kepala Negara, mempunyai otoritas untuk membuat aturan hukum dalam konteks bernegara.

Masalah yang timbul berkaitan dengan regulasi pertanahan, baik dalam hukum Islam maupun undang-undang adalah lahirnya nuansa otoritarianisme penguasa untuk mencabut hak kepemilikan tanah rakyat atas nama pembangunan untuk kepentingan umum problem epistemonologis yang krisual dari materi hukum pertanahan adalah apa makna dan kriteria kepentingan umum sebagai dasar pembenaran intervensi pemerintah dalam pembatasan hak milik tanah warga Negaranya. ${ }^{18}$

\section{KESIMPULAN}

Berdasarkan pembahasan diatas, penulis mengambil kesimpulan:

1. Penyelesaian sengketa sertifikat Hak Guna Bangunan terdapat tiga cara yaitu, prosedur subtansi dan kepentingan. Adapun penyelesaian sengketa diluar Pengadilan dikenal dengan upaya perdamaian terbukti dalam Undang-Undang Nomor 5 Tahun 1986.

2. Pertimbangan hukum hakim terhadap sengketa Peradilan Tata Usaha Negara Makassar yang memiliki dua bagian, yang pertama pertimbangan terhadap hukum agrariyah berdasarkan pasal 23 Huruf (a) 1 dan 2 peraturan pemerintahan (PP) RI Nomor 24Tahun 1997 tentang pendaftaran Tanah dan pertimbangan terhadap hukum Peradilan Tata Usaha Negara berdasar pada pasal 107 Undang-Undang Nomor 5 Tahun 1986. Pandangan Hukum Islam tentang sengketa yaitu Umat manusia sebagai khalifah di muka bumi dituntut untuk menyelesaikan sengketa, karena manusia dibekali akal, pikiran dan wahyu dalam menata kehidupannya. Manusia harus mencari dan menemukan pola penyelesaian sengketa sehingga penegakan keadilan dapat terwujud, untuk mempertahankan haknya. Oleh karena itu dalam hukum islam setuju tentang penyelesaian sengketa di pengadilan Tata Usaha Negara Makassar berdasarkan firman Allah swt di dalam Al-qur'an.

\footnotetext{
${ }^{17}$ Andi Intan Cahyani, Peradilan dan Hukum Keperdataan Islam, h.91

${ }^{18}$ Ridwan, Pemilikan Rakyat dan Negara atas Tanah, h.14.
} 


\section{DAFTAR PUSTAKA}

Abdullah, Rozali. Hukum Acara Peradilan Tata Usaha Negara. Jakarta: PT. Raja Grafindo Persada, 1996.

Arfita, Rani. "Kedudukan Badan Pertanahan Nasional dalam Menghadapi Problematika Putusan PTUN Tentang Pembatalan Sertifikat Hak Atas Tanah", Jurnal.umy Vol.23.No.1 (Juni 2016). ac.id/index.

Asni. Pembaharuan Hukum Islam. Jakarta: Kementrian Agama Republik Indonesia, 2012.

Bariyah, Oneng Nurul. Materi Hadits. Jakarta: Radar Jaya Ofiset, 2008.

Cahyani, Andi Intan. Peradilan dan Hukum Keperdataan Islam, Makassar: Alauddin University Press, 2014.

Harahap, Zairin. Hukum Acara Peradilan Tata Usaha Negara, Jakarta: PT. Raja Grafindo Persada, 2008.

Harsono, Boedi. Hukum Agraria Indonesia, Sejarah Pembentukan Undang-Undang Pokok Agraria Isi dan Pelaksanaannya. Jakarta: Djambatan, 2013.

Ismaya, Samun. Hukum Administrasi Petanahan. Yogyakarta: Graha Ilmu, 2013.

Kementrian Agama RI, Al-Qur'an dan Terjemahnya. Jakarta: CV. Al-Qolam Publishing, 2014.

Khaleed, Badriyah. Mekanisme Pengadilan Tata Usaha Negara. Yogyakarta: Pustaka Yustisia, 2016.

Mahpud, Moh. Perdebatan Hukum Tata Negara, Jakarta: PT. Raja Grafindo Persada, 2010.

Maria, S.W Soemarjono. Pelaksanaan Tugas Keorganisasian dalam Pembangunan Jakarta: Depertemen dalam Negeri Direktorat Jenderal Agraria, 1980.

Marihot, Pahala Siahaan. Bea Perolehan Hak Atas Tanah dan Bangunan. Jakarta: CV. Sagung Seto, 2011.

Muljadi, Kartini. Hak-Hak Atas Tanah. Jakarta: Kencana, 2014.

Murad, Rusmadi. Administrasi Pertanahan. Bandung: CV Mandar Maju, 2013.

Nazir, Moh. Metode Penelitian. Bogor: Ghalia Indonesia, 2005.

Noor, Juliansyah. Metodologi Penelitian: Skripsi, tesis, Disertasi, dan Karya Ilmiah. Jakarta: Kencana, 2011.

Petrus R.G. Sinaga. Sertifikat Hak Atas Tanah dan Implikasi Terhadap Kepastian Kepemilikan Tanah. Vol.II/No. 7 Agustus 2014. Petrus-R.G.Sinaga.ac.id.

Putra, Fani Martiawan Kumala. "Pembatalan Sertifikat Hak Atas Tanah karena Cacat Administrasif serta Implikasinya terhadap Tanah yang akan di Jaminkan", jaurnal-perspektif. Vol. XX No.2. (Mei 2015).

Ridwan, Pemilikan Rakyat dan Negara Atas Tanah Menurut Hukum Pertanahan Indonesia dan Pespektif Hukum Islam. Cet. I; Jakarta: Badan Litbang dan Diklat Kementrian Agama, 2010.

Ridwan. Hukum Administrasi Negara. Jakarta: PT. Raja Grafindi Persada, 2014.

Safriani, Andi. Hukum Administrasi Negara. Makassar: Alauddin University Press, 2013.

Siahaan, Marihot Pahala. Hak Atas Tanah dan Bangunan. Jakarta: PT. Grafindo, 2013.

Soehino. Asas-Asas Hukum Tata Usaha Negara. Yogyakarta: Liberty, 1998.

Soerjono Soekanto dan Sri Mamuji. Penelitian Hukum Normatif. Jakarta: Radjawali, 1985. 
Sugiono, Metode Penelitian Kuantitatif, Kualitatif dan $R \&$ \& . Bandung: Alfabet, 2009.

Suwardi, Endarsawara. Penelitian Kebudayaan: Idiologi, Epistimologi dan Aplikasi, Yogyakarta: Pustaka Widyatama, 2006.

Universitas Islam Negeri Alauddin Makassar. Pedoman Penelitian Karya Tulis Ilmiah: Makalah, Skripsi, Tesis, Disertasi, dan Laporan Penelitian. Makassar: Alauddin Press, 2013.

Wijayanti, Sri. Kepastian Hukum Sertifikat Hak Atas Tanah Sebagai Bukti Hak kepemilikan Tanah, Vol.16. 2010.

Wiyono. Hukum Acara Peradilan Tata Usaha Negara. Jakarta: Sinar Grafika, 2008.

Yanto, Nur. Hukum Acara Peradilan Tata Usaha Negara. Jakarta: Mitra Wacana Media, 2015. 